\title{
ZnO Nanorods with High Photocatalytic and Antibacterial Activity under Solar Light Irradiation
}

\author{
Faouzi Achouri ${ }^{1,2,3}$, Christophe Merlin ${ }^{4}$, Serge Corbel ${ }^{1}{ }^{(1)}$, Halima Alem ${ }^{5}(\mathbb{D}$, \\ Laurence Mathieu ${ }^{4,6}\left(\mathbb{D}\right.$, Lavinia Balan ${ }^{7} \oplus$, Ghouti Medjahdi ${ }^{5}$, Myriam Ben Said ${ }^{2}$, \\ Ahmed Ghrabi ${ }^{2}$ a and Raphaël Schneider ${ }^{1, *(\mathbb{D})}$ \\ 1 Université de Lorraine, CNRS, LRGP, F-54000 Nancy, France; achouri87@gmail.com (F.A.); \\ serge.corbel@univ-lorraine.fr (S.C.) \\ 2 Centre de Recherches et Technologies des Eaux (CERTE), Laboratoire Eaux Usées et Environnement, \\ P.O. Box 273, Soliman, Tunis 8020, Tunisia; myriam_rebia@yahoo.fr (M.B.S.); a.ghrabi@yahoo.fr (A.G.) \\ 3 Faculté des Sciences de Bizerte, Université de Carthage, Jarzouna, Bizerte 7021, Tunisia \\ 4 Université de Lorraine, CNRS, LCPME, F-5v4000 Nancy, France; christophe.merlin@univ-lorraine.fr (C.M.); \\ laurence.mathieu@univ-lorraine.fr (L.M.) \\ 5 Université de Lorraine, CNRS, IJL, F-54000 Nancy, France; halima.alem@univ-lorraine.fr (H.A.); \\ ghouti.medjahdi@univ-lorraine.fr (G.M.) \\ 6 EPHE, PSL Research University, LCPME, UMR 7564 Nancy, France \\ 7 IS2M, CNRS UMR 7361, 15 Rue Jean Starcky, 68093 Mulhouse, France; lavinia.balan@uha.fr \\ * Correspondence: raphael.schneider@univ-lorraine.fr; Tel.: +33-3-7274-3790
}

Received: 4 October 2018; Accepted: 29 October 2018; Published: 1 November 2018

check for updates

\begin{abstract}
ZnO}$ nanorods (NRs) with an average length and diameter of 186 and $20 \mathrm{~nm}$, respectively, were prepared through a mild solvothermal route and used as photocatalysts either as dispersed powder or immobilized on glass slides. The ZnO NRs were characterized by scanning electron microscopy (SEM), transmission electron microscopy (TEM), and X-ray diffraction (XRD). Dispersed ZnO NRs and, to a lesser extent, immobilized ZnO NRs were demonstrated to exhibit high photocatalytic activity under simulated sunlight of low intensity $\left(5.5 \mathrm{~mW} / \mathrm{cm}^{2}\right)$ both for the degradation of the Orange II dye and for Escherichia coli bacterial decontamination (2.5-fold survival decrease after $180 \mathrm{~min}$ irradiation for immobilized NRs). SEM, atomic force microscopy (AFM), fluorescence spectroscopy, and epifluorescence microscopy demonstrate that cell surface damages are responsible of bacterial inactivation. The immobilized $\mathrm{ZnO}$ NRs could be reused up to five times for bacterial decontamination at comparable efficiency and therefore have great potential for real environmental applications.
\end{abstract}

Keywords: $\mathrm{ZnO}$; photocatalysis; immobilized catalyst; Escherichia coli; bacterial decontamination

\section{Introduction}

Since the first report of bacterial photocatalytic inactivation in 1985 [1], photocatalysis has gained considerable interest regarding the decontamination of numerous pathogenic microorganisms, such as bacteria, viruses, fungi, and protozoa, in drinking and wastewater [2-7]. Once the photocatalyst is activated by light with an energy equal to or greater than the bandgap of the semiconductor, electron $\left(\mathrm{e}^{-}\right) /$hole $\left(\mathrm{h}^{+}\right)$pairs are generated in the conduction and valence bands, respectively. Next, some of these pairs migrate to the photocatalyst surface. In the primary stage, $\mathrm{e}^{-}$react with $\mathrm{O}_{2}$ adsorbed at the photocatalyst surface to generate superoxide $\mathrm{O}_{2}^{\bullet-}$ radicals, while $\mathrm{h}^{+}$react with water to produce hydroxyl ${ }^{\bullet} \mathrm{OH}$ radicals. These reactive oxygen species (ROS) are powerful oxidants able to mineralize organic pollutants and also affect the integrity of microorganisms, from their cell envelope to intracellular components such as proteins and DNA [2-7]. 
Zinc oxide $(\mathrm{ZnO})$ is an n-type direct bandgap semiconductor $(E g=3.3 \mathrm{eV})$ and has a large exciton binding energy ( $60 \mathrm{meV}$ at room temperature). Due to its attractive optical and electronic properties, $\mathrm{ZnO}$ has found applications in solar cells, optical coatings, and electrical devices [8-11]. Although $\mathrm{ZnO}$ exhibits a slightly lower photostability than $\mathrm{TiO}_{2}$ [12], it has also been demonstrated as being one of the most promising materials for photocatalytic applications such as degradation of organic pollutants and microorganism decontamination [13-15]. The native defects present in $\mathrm{ZnO}$, such as oxygen vacancies and zinc interstitials, not only allow the decrease of $\mathrm{e}^{-} / \mathrm{h}^{+}$pair recombinations but also the increase of visible light absorption [16,17]. Moreover, due to its good physical and chemical stability, $\mathrm{ZnO}$ possesses a photocatalytic activity comparable to that of $\mathrm{TiO}_{2}$. Another interesting aspect of $\mathrm{ZnO}$, especially for photocatalytic applications, is that various nanostructures with different morphologies (spheres, rods, tubes, needles, etc.) can be engineered using relatively simple and mild methods (sol-gel, solvothermal, etc.) without any templates or surfactants. Numerous reports have demonstrated that the photocatalytic efficiency depends on $\mathrm{ZnO}$ particle size and morphology [18,19]. One-dimensional nanostructures, like nanorods, formed by electrostatic interactions between $\mathrm{ZnO}$ clusters [20-22], generally exhibit a higher photocatalytic activity than spherical $\mathrm{ZnO}$ particles due to their high surface area that allows more light to be trapped, thus generating more charge carriers [18,19,22-26]. Moreover, due to their dimensional anisotropy, more $\mathrm{e}^{-}$and $\mathrm{h}^{+}$exist on active sites at the catalyst surface, leading to increased ROS generation.

Recently, we described the synthesis and the photocatalytic activity of small-sized undoped and doped $\mathrm{ZnO}$ rods that have a good potential for water decontamination due to the presence of defect sites that favor light absorption and hinder $\mathrm{e}^{-} / \mathrm{h}^{+}$recombination and to their high specific surface area $[22,23,27]$. However, the facile recovery, handling, and reuse of the photocatalyst after water decontamination is the stumbling block for the development and wide use of this photocatalysis technology. In that context, the use of immobilized photocatalysts can be one alternative. Moreover, immobilization avoids working with small particles that are subject to agglomeration and also to the release of $\mathrm{ZnO}$ in the environment. The main drawback associated with particle immobilization is the decrease of the catalyst specific surface area and thus of its reactivity [28,29]. This hurdle might be overcome through the use of nanosized $\mathrm{ZnO}$ particles with a high surface-to-volume ratio in which a high density of active sites for adsorption and photodegradation can be maintained.

In this paper, we report the preparation of $\mathrm{ZnO}$ nanorods (NRs) with an average length and diameter of ca. 186 and $20 \mathrm{~nm}$, respectively, and their successful immobilization on glass slides by a mild thermal treatment at $70{ }^{\circ} \mathrm{C}$. The photocatalytic activity of $\mathrm{ZnO}$ NRs, both in dispersed and immobilized forms, was explored under simulated sunlight irradiation through the degradation of the Orange II dye used as model pollutant. ZnO NRs also exhibited excellent photoinactivation activity toward Escherichia coli cells, and the immobilized $\mathrm{ZnO}$ photocatalyst could be reused up to five times for bacterial inactivation without significant loss of its activity, indicating its great potential for water treatment.

\section{Materials and Methods}

$\mathrm{ZnO}$ NRs were prepared via a solvothermal method according to reference [30]. The full synthetic protocol and the methods used to characterize these particles are provided in the Supplementary Materials.

\subsection{Photocatalytic Degradation of Orange II}

The photocatalytic activity of $\mathrm{ZnO}$ NRs was evaluated by the degradation of an aqueous solution of the Orange II dye $(10 \mathrm{mg} / \mathrm{L})$ at $25^{\circ} \mathrm{C}$ under simulated sunlight irradiation produced by Sylvania LuxLine FHO T5 neon tubes (see Figure S1 for the UV-visible emission spectrum of the tubes used). The intensity at the surface of the dye solution was estimated to be $5.5 \mathrm{~mW} / \mathrm{cm}^{2}$. In the case of dispersed $\mathrm{ZnO}$ NRs, the photocatalyst $(40 \mathrm{mg}$ ) was dispersed in $40 \mathrm{~mL}$ of Orange II solution and the suspension was stirred for $30 \mathrm{~min}$ in the dark to achieve an adsorption-desorption equilibrium. Under stirring, the suspension was exposed to light irradiation. At certain time intervals, $1 \mathrm{~mL}$ of 
the suspension was extracted and centrifuged (15,000 rpm for $2 \mathrm{~min})$ to remove the photocatalyst. The degradation process was monitored by measuring the UV-visible absorption of Orange II at $485 \mathrm{~nm}$.

For experiments conducted with immobilized ZnO NRs, 10 glass slides, accounting for a total area of $87.5 \mathrm{~cm}^{2}$ and covered by $148.5 \mathrm{mg}$ of photocatalyst, were introduced in a glass Petri dish. Next, $60 \mathrm{~mL}$ of the Orange II solution was added and the photodegradation was monitored as previously.

\subsection{Photocatalytic Inactivation of E. coli}

The E. coli strain MG1655 [31] was used as model bacteria for all photocatalytic inactivation tests (see the Supplementary Materials for the growth conditions). For each experiment, four conditions were used, namely, with and without photocatalyst, and with and without light irradiation. For the experiments with the dispersed photocalyst, $20 \mathrm{~mL}$ of E. coli MG1655 cells suspension $\left(10^{6} \mathrm{CFU} / \mathrm{mL}\right.$ ) was mixed with $20 \mathrm{mg}$ of $\mathrm{ZnO}$ NRs (final concentration $1 \mathrm{~g} / \mathrm{L}$ ) in a 100-mL sterile beaker. The bacteria/ZnO NRs mixtures were then either irradiated or kept in the dark for $3 \mathrm{~h}$ under stirring. Serial dilutions were performed in sterile demineralized water and aliquots were plated on LB agar for $24 \mathrm{~h}$ at $37^{\circ} \mathrm{C}$ for the estimation of viable cultivable cells. Each experiment was repeated three times for assessing reproducibility. For the experiments with the immobilized photocatalyst, $260 \mathrm{mg}$ of $\mathrm{ZnO}$ NRs was dispersed in $60 \mathrm{~mL}$ of demineralized water and immobilized on 10 glass slides. Five of these slides were used for the control experiments conducted in the dark and five for photocatalytic experiments. In both conditions, $50 \mathrm{~mL}$ of the bacterial suspension $\left(5 \times 10^{5} \mathrm{CFU} / \mathrm{mL}\right)$ was introduced into a Petri dish $(\mathrm{ID}=120 \mathrm{~mm}$ ) containing the $\mathrm{ZnO}$ covered glass slides.

\subsection{Fluorescence Spectroscopy Measurements}

Direct interactions between the bacteria proteins and $\mathrm{ZnO}$ NRs during photocatalytic experiments were estimated by monitoring the tryptophan (Trp) fluorescence emission at $331 \mathrm{~nm}$ following an excitation at $295 \mathrm{~nm}$. Bacteria samples were taken during the photocatalytic experiment and the Trp fluorescence was measured after vortexing.

\subsection{Estimation of Cell Membrane Integrity by Fluorescence Microscopy}

Bacterial cell counts were determined microscopically after SYBR Green II (Thermo Fisher, Courtaboeuf, France) and propidium iodide (PI) staining (Sigma Aldrich, Saint Quentin Fallavier, France). After contact (or not) with dispersed or immobilized NRs, cell suspensions ( $2 \mathrm{~mL})$ were stained both by SYBR Green II (final concentration 10X) and PI (final concentration $0.6 \mathrm{mM}$ ) for $15 \mathrm{~min}$ in the dark. After staining, the suspension was filtered through a $25-\mathrm{mm}$ diameter, $0.2-\mu \mathrm{m}$ pore-size black polycarbonate membrane (Whatman, Piscataway, NJ, USA), air dried, and mounted in mounting oil. Cell counts were carried out with an epifluorescence microscope (BX40, Olympus, Tokyo, Japan) equipped with a $\times 100$ immersion objective lens, a 470-490-nm excitation filter, and a 520-nm barrier filter. Undamaged cells (SYBR-Green-stained cells) and membrane-damaged cells (PI red-stained cells) were enumerated using 60 randomly chosen fields. The results were expressed as cells $/ \mathrm{mL}$.

\subsection{Assessing Cell Alteration by Flow Cytometry}

Cells suspensions were washed and resuspended as previously described except that a $0.85 \%$ $\mathrm{NaCl}$ saline buffer filtered beforehand $(0.2 \mu \mathrm{m})$ was used to limit contaminating particle impurities. Cells were subsequently stained (or not) with SYBR Green II (10X final concentration) for $15 \mathrm{~min}$ and analyzed by flow cytometry (BD Accuri ${ }^{\mathrm{TM}}$ C6, BD Biosciences, San Jose, CA, USA) equipped with a 50-mW laser emitting at $488 \mathrm{~nm}$. Commercial distilled apyrogen sterile ultrapure water (B-Braun water, B-Braun, Melsungen, Germany) was used as sheath fluid. Bacteria DNA stained with SYBR Green II fluorescence intensity were collected at FL2 channel ( $\left.\lambda_{\mathrm{em}}: 510 \pm 15 \mathrm{~nm}\right)$, as well as forward (FSC) and sideward (SSC) scattered light intensities that give an estimation of the size and granularity of the cells, respectively. Events were triggered on the forward scatter parameter with a threshold 
of 5000 a.u. and on FL2 with a threshold of 2000 a.u. to narrow the signal to fluorescent cells and to separate positive signals (stained cells) from background. This gating was kept the same for all samples in order to achieve comparable data. The data were analyzed using BD Accuri ${ }^{\mathrm{TM}} \mathrm{C} 6$ software (BD Biosciences). Event counts provide an estimation of the total cell amount (damaged plus live cells), while the stability of the mean fluorescence reflects the integrity of the intracellular nucleic acid.

\subsection{Scanning Electron Microscope (SEM) Observations of E. coli Cells}

During the photocatalytic inactivation tests of E. coli, samples of cell suspensions were centrifuged to remove the $\mathrm{NaCl}$ solution and then fixed with $2.5 \%$ glutaraldehyde for $2 \mathrm{~h}$. Next, the cells were dehydrated through a graded series of ethanol solutions (37\%, 67\%, 95\%, and 100\%) for $15 \mathrm{~min}$ and observed using a JSM-6490 LV scanning electron microscope (JEOL, Tokyo, Japan).

\subsection{E. coli Cell Morphology Analysis by Atomic Force Microscopy (AFM)}

The E. coli MG1655 cell morphology was investigated by AFM in intermittent contact mode (Tapping mode) on an Asylum Research MFP-3D Infinity ${ }^{\mathrm{TM}}$ equipped with a 100- $\mu \mathrm{m}$ close-loop scanner (Asylum Research, Santa Barbara, CA, USA). Bacterial cell suspensions were deposited on a glass slide and then air dried at room temperature before observation. Point probe robes (Asylum Research, Santa Barbara, CA, USA) were used. The cantilevers had a resonance frequency around $270 \mathrm{kHz}$ and spring constant values around $26 \mathrm{~N} \cdot \mathrm{m}^{-1}$. Images were acquired with a drive amplitude of $15 \mathrm{mV}$ and an attenuation set-point of 0.8 to 0.7. At least five different zones were scanned on each sample and images at different magnifications were acquired (only $5 \times 5 \mu \mathrm{m}^{2}$ and $1 \times 1 \mu \mathrm{m}^{2}$ images are shown). The images were treated and analyzed using procedures developed under Igor (version Pro 7, Wavemetrics, Asylum, Portland, OR, USA).

\section{Results}

\subsection{Synthesis and Characterization of $\mathrm{ZnO} N R s$}

$\mathrm{ZnO}$ NRs were prepared via a sol-gel process by treatment of $\mathrm{Zn}(\mathrm{OAc})_{2}$ with $\mathrm{NaOH}$ in ethanol at $60{ }^{\circ} \mathrm{C}$ [30]. Figure 1a shows the X-ray diffraction (XRD) pattern of the NRs obtained after $72 \mathrm{~h}$ reaction at $60^{\circ} \mathrm{C}$. All diffraction peaks are intense and narrow, which indicates that the NRs are highly crystalline. All peaks correspond to the hexagonal wurtzite structure of $\mathrm{ZnO}$ with cell constants of $\mathrm{a}=0.3251 \mathrm{~nm}$ and $\mathrm{c}=0.5208 \mathrm{~nm}$ (JCPDS Card No. 36-1451) and no impurities were detected. SEM and transmission electron microscopy (TEM) data collected for the same nanocrystals are shown in Figure 1b,c. Analysis of ca. 100 particles indicates that the ZnO NRs have an average length of $186 \mathrm{~nm}$ and a diameter of ca. $20 \mathrm{~nm}$ and that their size distribution is relatively narrow. The high crystallinity of the particles is further evidenced from the selected area electron diffraction (SAED) pattern shown in the inset of Figure $1 \mathrm{c}$ and from the HR-TEM image that shows continuous lattice fringes through the whole particle (Figure 1d). The interplanar spacing is $0.26 \mathrm{~nm}$ and corresponds well to the (002) plane of wurtzite $\mathrm{ZnO}$. The UV-visible diffuse reflectance spectrum of $\mathrm{ZnO}$ NRs is shown in Figure S2. The bandgap energy of $\mathrm{ZnO}$ NRs $(3.25 \mathrm{eV}$ ) was determined from their $\mathrm{UV}$-visible diffuse reflectance spectrum and by plotting $[\mathrm{F}(\mathrm{R}) \mathrm{hv}]^{2}$ vs. photon energy followed by extrapolating the plots at $[\mathrm{F}(\mathrm{R}) \mathrm{h} v]^{2}$ $=0(\mathrm{~F}(\mathrm{R})$ is the Kubelka-Munk function, $\mathrm{h}$ is the Planck constant, and $v$ is the frequency) (Figure S2).

For practical applications and to easily reuse the photocatalyst without separation via centrifugation or filtration, the $\mathrm{ZnO}$ NRs were immobilized on microscope glass slides. For that purpose, an aqueous dispersion of the $\mathrm{ZnO}$ NRs was deposited on glass slides followed by a thermal treatment at $70{ }^{\circ} \mathrm{C}$ for $12 \mathrm{~h}$. The SEM images of the immobilized catalyst demonstrate that the size and the morphology of the NRs were not altered by this treatment (Figure 2a). The thickness of the $\mathrm{ZnO}$ NR layer deposited was estimated to be $650 \mu \mathrm{m}$ (Figure 2b). 

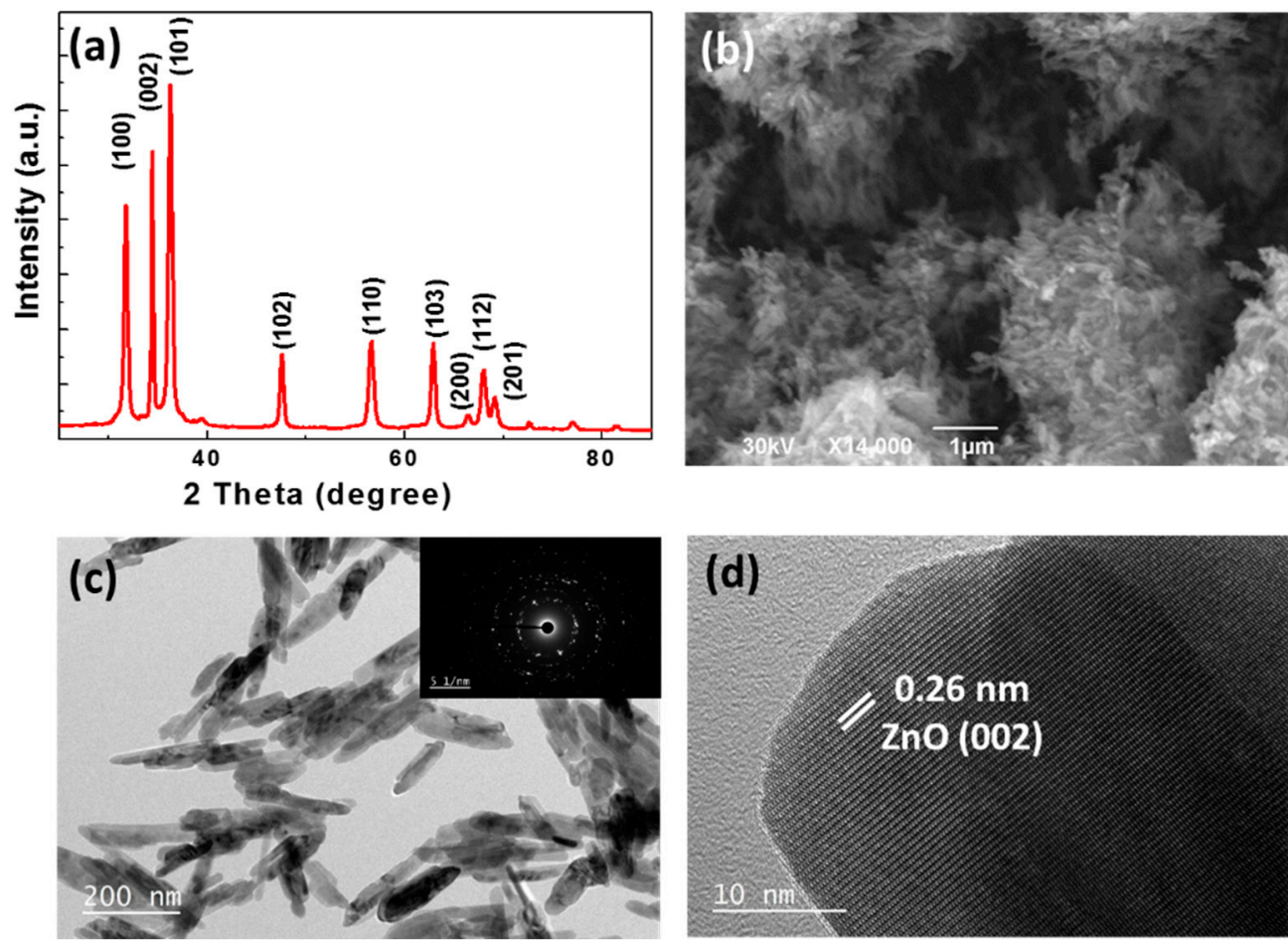

Figure 1. (a) X-ray diffraction (XRD) pattern, (b) scanning electron microscopy (SEM), and (c,d) transmission electron microscopy (TEM) images of the ZnO nanorods (NRs) (the inset of Figure 1c is the selected area electron diffraction (SAED) pattern).
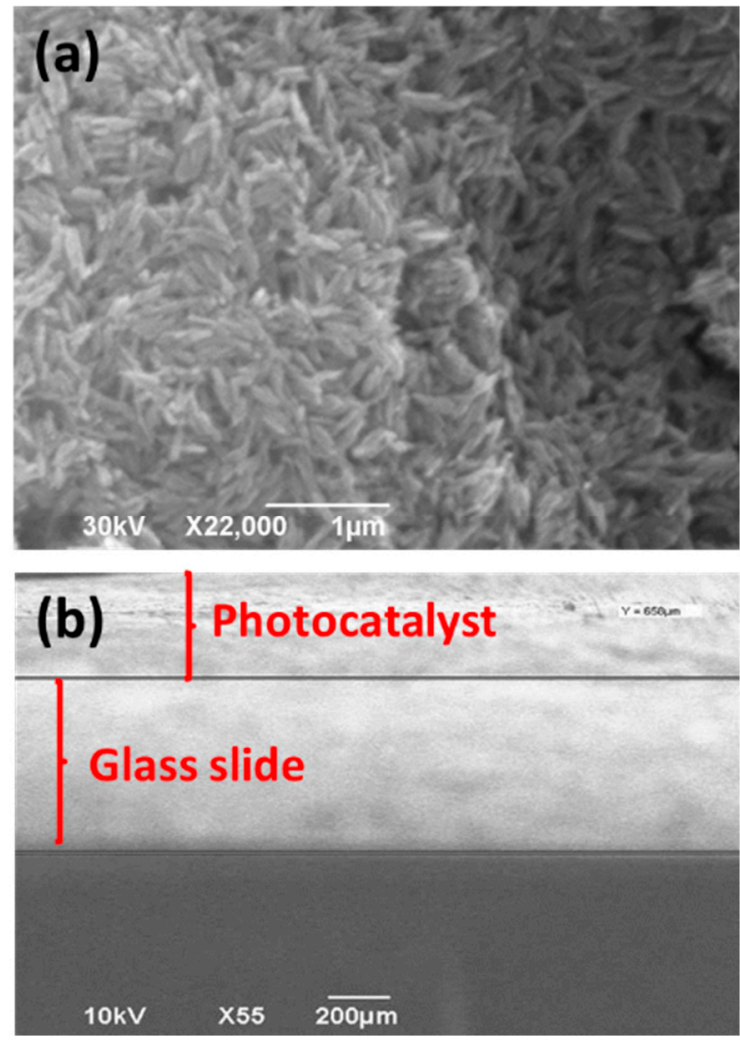

Figure 2. SEM images of the immobilized $\mathrm{ZnO}$ photocatalyst (a) top view and (b) cross sectional view. 


\subsection{Photocatalytic Degradation of Orange II}

The photocatalytic efficiency of ZnO NRs, used either as powder or as film, was first evaluated in a degradation test of a 10-mg/L Orange II aqueous solution under simulated sunlight irradiation $\left(5.5 \mathrm{~mW} / \mathrm{cm}^{2}\right)$. Due to their bandgap of $3.25 \mathrm{eV}, \mathrm{ZnO}$ NRs can only be photoactivated by light with a wavelength lower than ca. $381 \mathrm{~nm}$. Photocatalytic experiments were conducted under sunlight irradiation to demonstrate that this light source can successfully be used for the degradation of dyes or bacteria (vide infra). For experiments conducted with the dispersed $\mathrm{ZnO} N R s, 40 \mathrm{mg}$ of photocatalyst was mixed in $40 \mathrm{~mL}$ of the Orange II aqueous solution. For the immobilized catalyst, $148.5 \mathrm{mg}$ of the ZnO NRs deposited on glass slides was immersed into $60 \mathrm{~mL}$ of the Orange II solution.

Preliminary blank experiments demonstrated that, in the absence of the catalyst, no bleaching of the dye was observed after $5 \mathrm{~h}$ of irradiation. Once the photocatalyst was added, and after reaching the adsorption-desorption equilibrium (ca. $30 \mathrm{~min}, 15 \%$ of Orange II adsorbed at the surface of $\mathrm{ZnO}$ NRs), a gradual decrease in the dye UV-visible absorption at $484 \mathrm{~nm}$ was observed as a function of the irradiation time (Figure S3). The complete disappearance of Orange II was obtained after $150 \mathrm{~min}$ irradiation with $40 \mathrm{mg}$ of $\mathrm{ZnO}$ NRs used as powder, and in $210 \mathrm{~min}$ with the immobilized photocatalyst (Figure 3a). The UV-visible emission spectrum of the lamp used for photocatalytic experiments and the absorption spectrum of Orange II are provided in Figures S1 and S2, respectively. An overlap between the two spectra can be observed, suggesting that the electrons photoexcited from the HOMO to the LUMO of Orange II may be transferred to the $\mathrm{CB}$ of $\mathrm{ZnO}$ and thus contribute to the photodegradation of the dye.

The efficiencies of Orange II degradation by ZnO NRs were determined quantitatively using the pseudo-first-order model $\ln \left(C / C_{0}\right)=-k t$, where $\mathrm{k}$ is the apparent rate constant $\left(\mathrm{min}^{-1}\right)$ and $\mathrm{C}_{0}$ and $\mathrm{C}$ are the concentrations of Orange II at time 0 and $\mathrm{t}$, respectively (Figure S4). The rate constants $\mathrm{k}$ determined for the bleaching of the dye solution were found to be 0.016 and $0.004 \mathrm{~min}^{-1}$ for $\mathrm{ZnO}$ NRs used as powder and as film, respectively (results were normalized relative to the mass of $\mathrm{ZnO}$ NRs and to the volume of the Orange II solution). The lower photocatalytic activity observed for the immobilized catalyst likely originates from both its lower specific surface compared to dispersed $\mathrm{ZnO}$ NRs and the mass transfer limitation, and thus from the reduced probability of contact between the dye and the photocatalyst as reported in studies dedicated to $\mathrm{TiO}_{2}$ photocatalysts [32-34].

The stability and the reusability of the photocatalyst were investigated using the immobilized $\mathrm{ZnO}$ NRs without any washing or drying treatment between two runs (Figure 3b). As can be seen, no significant decrease of catalytic activity could be observed during the 10 successive cycles of Orange II photodegradation. Moreover, XRD and SEM experiments demonstrate that the crystallinity and the morphology of deposited particles were not altered during the repeated experiments (Figures S5 and S6).
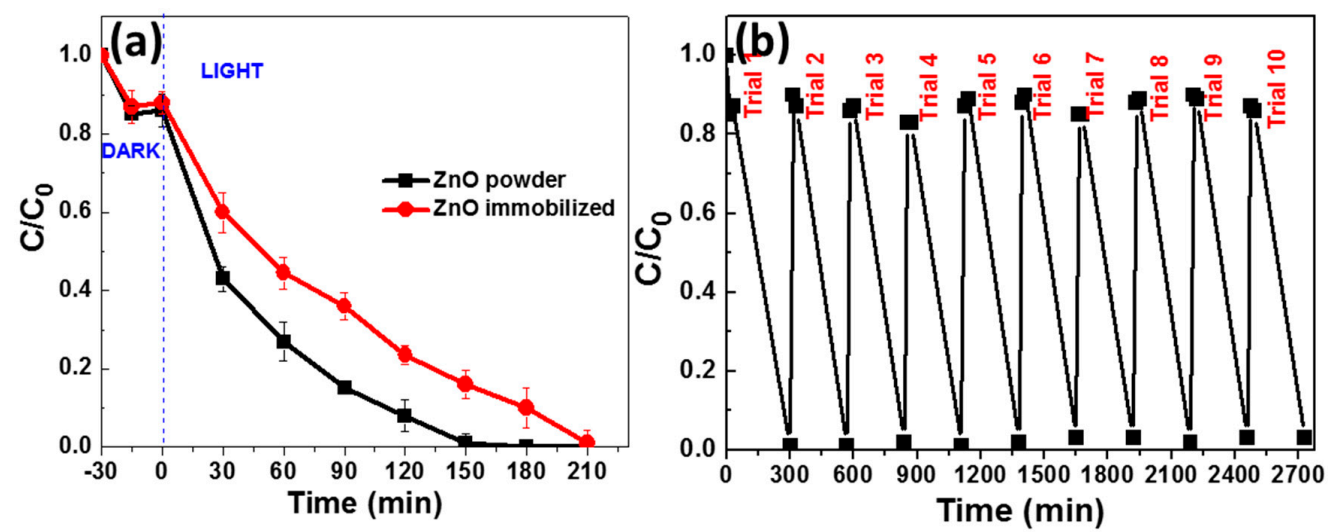

Figure 3. (a) Variation of the Orange II concentration as a function of irradiation time (C is the concentration at time $\mathrm{t}$, and $\mathrm{C}_{0}$ is the initial concentration). (b) Reusability of $\mathrm{ZnO}$ NRs fixed on glass slides. Experiments were performed under simulated sunlight irradiation (intensity of $5.5 \mathrm{~mW} / \mathrm{cm}^{2}$ ). 


\subsection{Photocatalytic Inactivation of E. coli MG1655}

Figure 4 shows the bacterial inactivation of suspended E. coli MG1655 cells using dispersed and fixed photocatalysts. Control experiments (under light irradiation but in the absence of the photocatalyst or with the photocatalyst used in the dark) are also provided as reference. Simulated sunlight irradiation has no detectable effect on the E. coli MG1655 cultivability in the absence of the photocatalyst as seen by growth on nutritive medium. Dispersed and immobilized ZnO NRs used in the dark induce a 10-fold and 3-fold decrease of cell viability after $3 \mathrm{~h}$, respectively, thus indicating that these particles exhibit toxicity towards bacteria even in the absence of light activation. These results are in good agreement with previous reports demonstrating that $\mathrm{ZnO}$ particles could be toxic to bacteria even in the dark. This toxicity may originate either from the association of $\mathrm{ZnO}$ NRs with the cell surface components leading to structural damages [35-38] or from the $\mathrm{Zn}^{2+}$ ions produced by the partial dissolution of $\mathrm{ZnO}$ particles followed by ROS generation [39-41].

The rates of bacterial inactivation were markedly enhanced when ZnO NRs were used under light irradiation and when increasing the irradiation time (Figure 4). With the dispersed catalyst, the bacterial survival showed a continuous decrease with time and a full cell inactivation (over a 6-log decrease) was observed past $3 \mathrm{~h}$. With immobilized $\mathrm{ZnO}$ NRs, the bacterial inactivation was moderate, with a 25-fold survival decrease over a 3-h photocatalysis. As previously observed with Orange II, the photocatalytic activity of the fixed catalyst is lower than that of the dispersed one. The stability of the immobilized photocatalyst during repeated bacterial inactivation was also evaluated. The same catalyst could be reused for five photocatalytic cycles after a simple washing with demineralized water without altering significantly the inactivation rate (from 1.22- to 1.15-log decrease over the five cycles) (Figure S7).

(a)

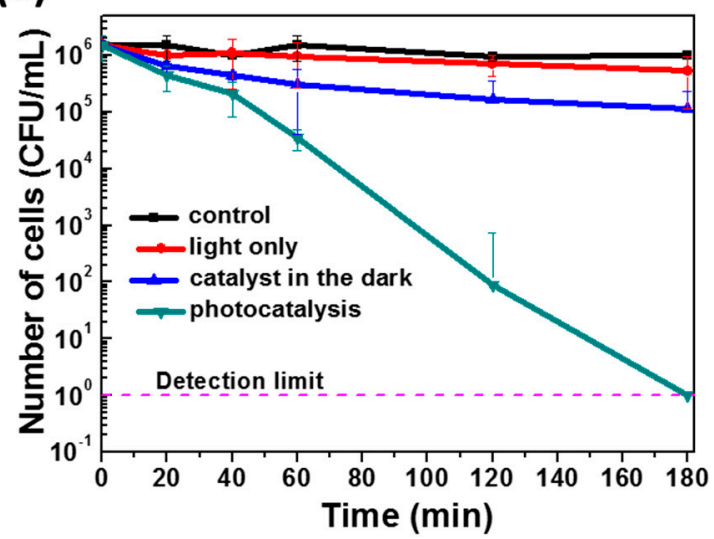

(b)

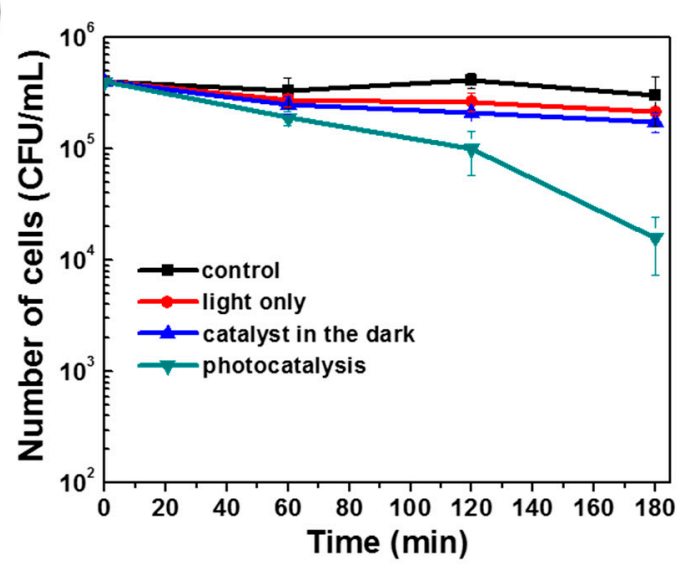

Figure 4. Loss of cultivability of E. coli MG1655 (colony forming units) during photocatalysis using (a) dispersed and (b) immobilized ZnO NRs. "Control" represents a light-free, ZnO-free condition, while "light only" corresponds to light-exposed cells in the absence of the photocatalyst.

We finally evaluated the influence of the amount of ZnO NRs immobilized onto the glass slides on the photocatalytic activity (Figure S8). Indeed, the amount of catalyst used is a key parameter in photocatalytic experiments because the pollutants or microorganisms have to be in the close vicinity of the photocatalyst surface in order to be degraded or inactivated. When two glass slides (covered by $52 \mathrm{mg}$ of $\mathrm{ZnO}$ NRs) were used instead of five slides (covered by ca. $130 \mathrm{mg}$ of $\mathrm{ZnO} \mathrm{NRs}$ ), the bacterial inactivation was reduced by ca. 10-fold, thus highlighting the key role played by the availability of the catalyst active sites (Figure S8).

\subsection{Bacterial Protein Interaction with $\mathrm{ZnO}$ Nanorods}

The fluorescence of Trp residues (located at $331 \mathrm{~nm}$ after excitation at $295 \mathrm{~nm}$ ) is very sensitive to its local environment and is often used to report alteration of protein structure/conformation [42-44]. 
In order to better understand the effects of photocatalysis on the loss of bacterial viability, we monitored the evolution of protein fluorescence associated with the Trp residues during photocatalytic experiments. As shown in Figure 5a,c, the intensity of the Trp fluorescence decreases by ca. 3.6-fold and 2-fold during photocatalytic experiments conducted with dispersed and immobilized ZnO NRs, respectively, which indicates changes in the local environment of the Trp residues. Interestingly, the strong decrease of the photoluminescence intensity observed with the dispersed photocatalyst is correlated with the marked losses of bacterial cultivability (colony forming units), thus indicating a close relationship between the local changes of protein conformations and the NR phototoxicity. Control experiments where bacteria were exposed to NRs in the dark showed a much weaker alteration of their Trp fluorescence profiles (Figure S9a in Supplementary Materials File 1). After $1 \mathrm{~h}$ of photocatalysis, the Trp fluorescence intensity was decreased by ca. 2.6-fold, while it was only of 1.1-fold when using the catalyst in the dark (Figure S9b in Supplementary Materials File 1). This indicates that local changes in the environment of the bacterial proteins are rather linked to the photocatalytic process and are unlikely to result from a direct bacteria/ZnO NR interaction as demonstrated by the minor decrease of fluorescence observed in the dark (Figure S9).
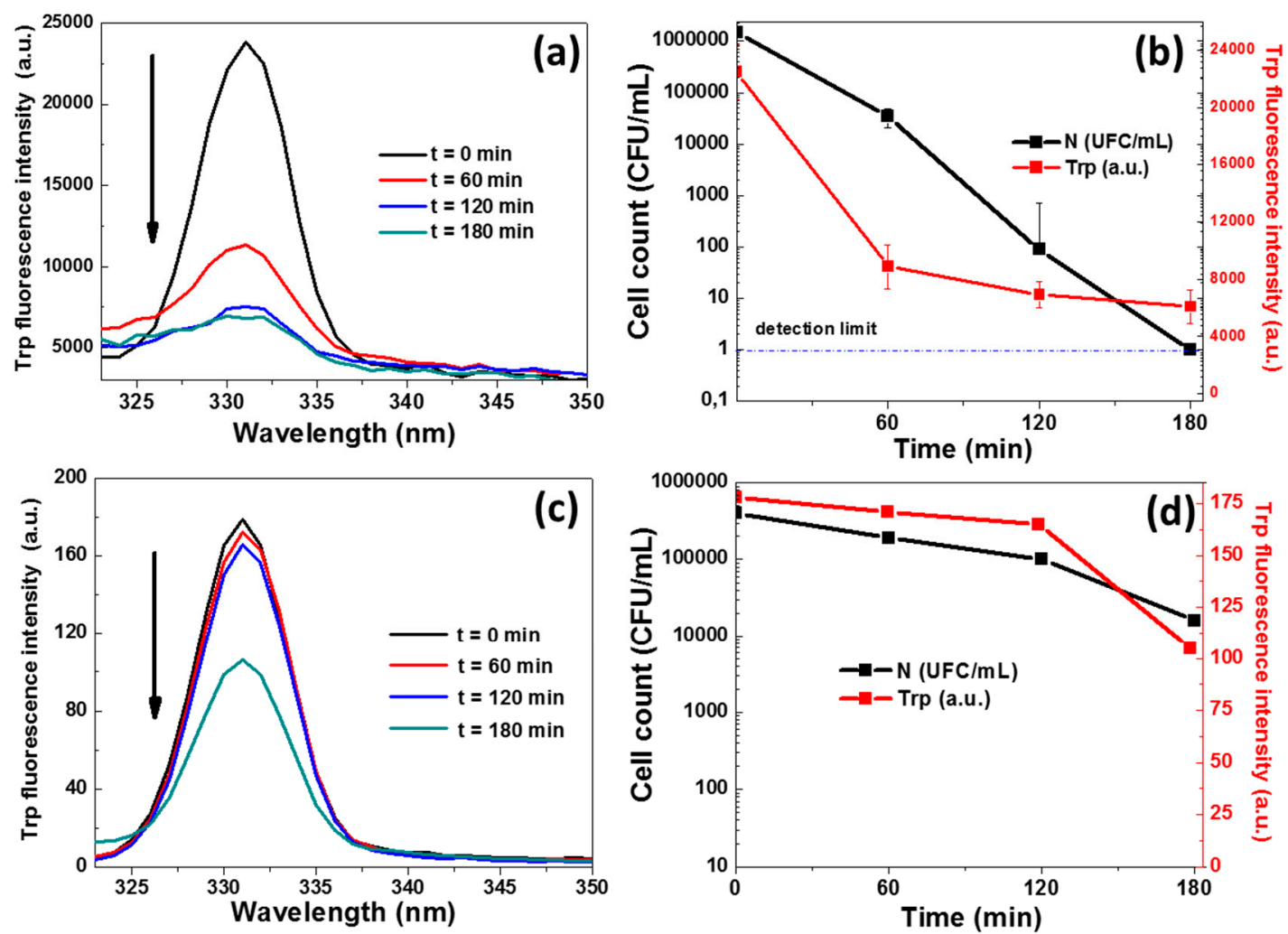

Figure 5. (a,c) Trp fluorescence emission spectra and (b,d) time evolution of Trp fluorescence intensity and bacterial cultivability (CFU) during photocatalytic experiments with $(\mathbf{a}, \mathbf{b})$ dispersed and (c,d) fixed ZnO NRs.

\subsection{Photocatalysis-Induced Cell Surface Alterations}

Considering that the decrease of the Trp fluorescence originates from changes in the local environment of some bacterial proteins, which in turn should not occur without cell structure damage, we further explored the effect of photocatalysis on bacterial membrane integrity. A series of experiments using epifluorescence microscopy was performed to analyze the changes induced on the bacterial cell membrane permeability during the photocatalytic treatment. These experiments were based on the dual labeling of bacterial DNA with SYBR Green II and propidium iodide (PI) fluorochromes that differ both in their spectral characteristics and their ability to cross cell membranes. 
Contrary to SYBR Green II, PI can enter the cell only when the cytoplasmic membrane integrity is compromised. Membrane damages were estimated on cell suspensions in saline buffer, with and without exposure to light, and with and without exposure to ZnO NRs (Figure 6). First, no major effects on membrane integrity could be detected in experiments where bacterial suspensions were exposed (or not) for 1 or $3 \mathrm{~h}$ to light irradiation (Figure S10b-e). The usual background of PI-stained cells observed at T0 by epifluorescence microscopy likely originates from an altered physiological state of part of the bacterial inoculum and/or from the preparation-associated damages to the cells by centrifugation, for instance. No significant alteration of bacterial membrane permeability was observed when exposing the bacteria to the immobilized ZnO NRs in the dark (Figure S9f-g). However, after $3 \mathrm{~h}$ of photocatalytic treatment, a marked increase of the number of bacteria with altered membrane (PI stained) was detected (64\% of membrane-damaged cells vs. $20 \%$ in the control), which is in agreement with both the loss of bacterial cultivability and the decrease of Trp fluorescence observed previously (Figures 4 and 5).

Next, flow cytometry (FCM) was applied in order to quantify SYBR Green II fluorescence in single cells and follow its modifications according to the treatments applied. FCM can be used to discriminate between low- and high-fluorescent bacteria after exposure to stress (chlorine, $\mathrm{UV}, \mathrm{H}_{2} \mathrm{O}_{2}$, etc.) [45], revealing an extinction of the fluorescence of the stressed bacteria that may be explained by nucleic acid alteration $[46,47]$. In particular, this has been demonstrated for pure bacterial strains [48-50] and on complex bacterial consortium [51,52]. In this context, $E$. coli cell suspensions were analyzed by FCM after exposure (or not) to $\mathrm{ZnO}$ NRs, and with or without light irradiation (cells not exposed to $\mathrm{ZnO}$ NRs were used as reference) (Figures 7 and S11). No reduction in the total cell counts was observed but a fraction of the bacteria lost their cultivability, further confirming that the photocatalytic-generated damages are not severe enough to fully disrupt the cells. On the other hand, the analysis of the mean fluorescence intensity of SYBR Green II showed a relatively stable nucleic acid staining, indicating that no detectable alteration of nucleic acids took place during the photocatalytic experiment as implemented. However, the intracellular levels of fluorescence were statistically compared two by two using a standard Z-test. None of the conditions produced a significant difference when the 1-h exposure time was analyzed. Small but significant differences were observed when comparing two incubation times for a given condition $\left(1 \mathrm{vs.} 3 \mathrm{~h} ; p<10^{-4}\right)$ or for the effect of light irradiation (dark versus light) but only at $3 \mathrm{~h}$ of irradiation $\left(p<10^{-4}\right)$. Altogether, these results suggest that the photocatalytic treatment mostly injured surface structures on E. coli cells, which resulted in altered cells that progressively lost their viability.

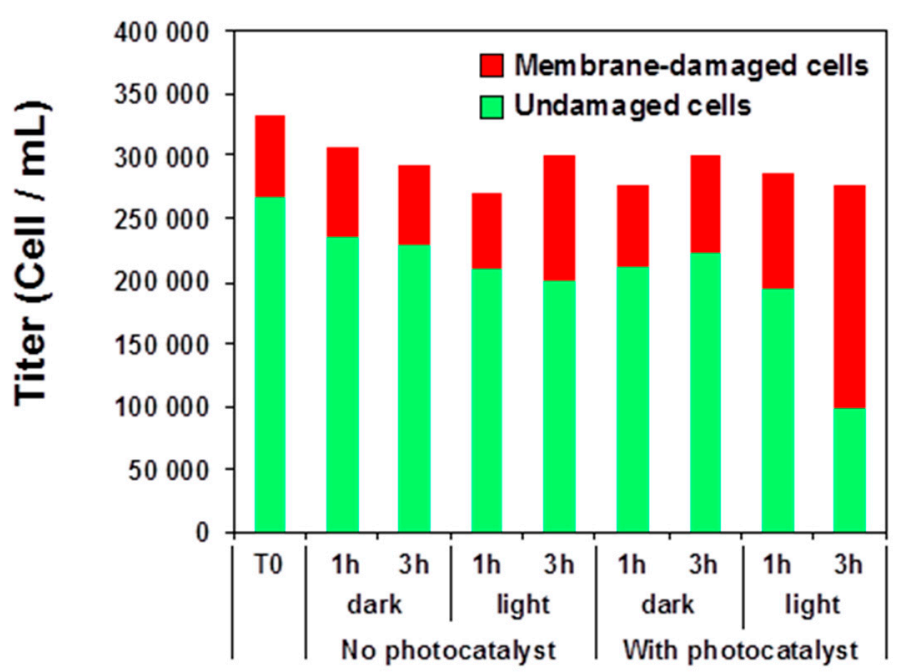

Figure 6. Enumeration of undamaged (SYBR Green II staining) and membrane-altered (propidium iodide (PI) staining) of bacteria by epifluorescence microscopy. 
(a)

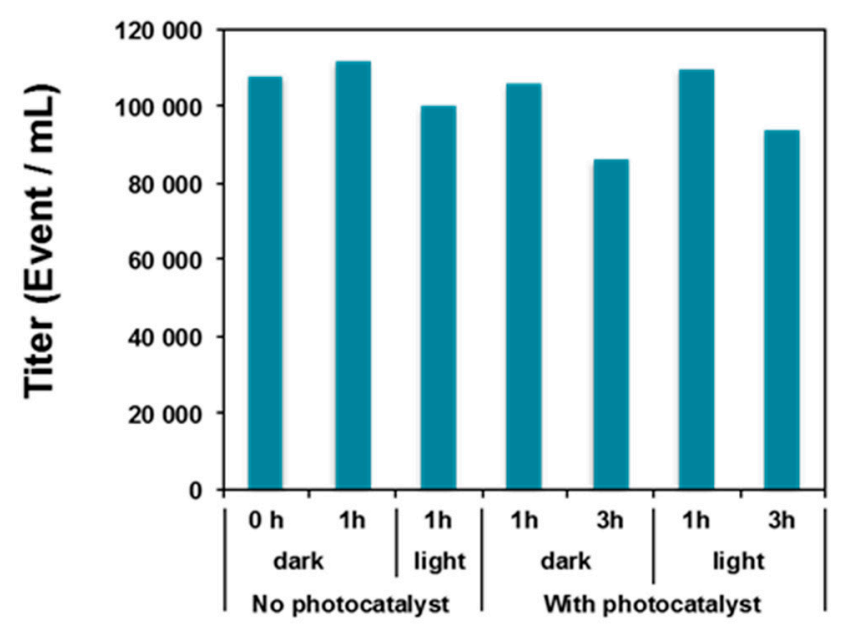

(b)

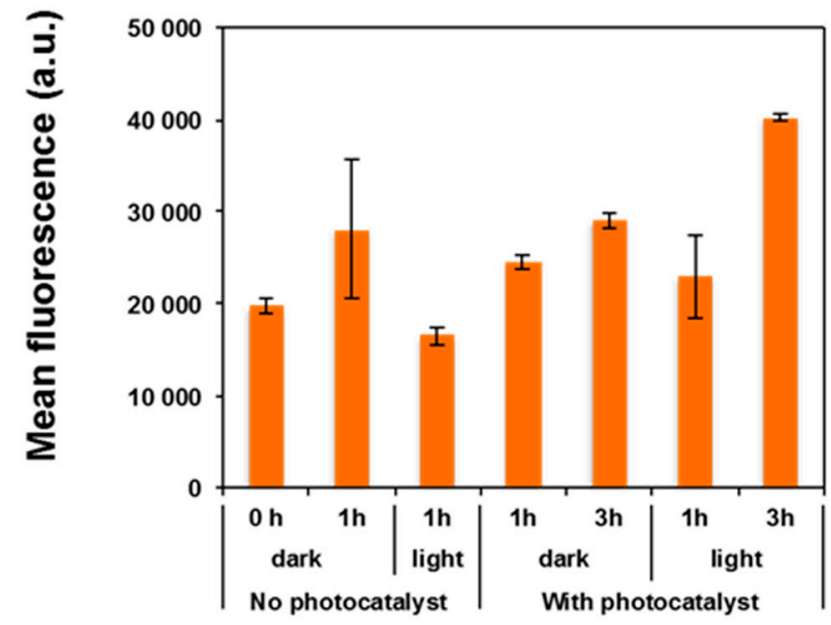

Figure 7. (a) Concentration of bacterial cells detected by flow cytometry (FCM) after SYBR Green II staining and (b) mean fluorescence intensity of the SYBR Green II fluorochromes per cells. Error bars represent Standard Error of the mean. Each data point represents 1900-3800 events acquired by FCM.

\subsection{Photocatalysis-Induced Cell Structure Damages}

Morphological alterations of E. coli cells $\left(10^{8} \mathrm{CFU} / \mathrm{mL}\right)$, generated by exposure to $\mathrm{ZnO}$ NRs under light irradiation or in the dark, were examined by SEM. Control E. coli cells appeared as rod-shaped cells with an average size varying between 1 and $2 \mu \mathrm{m}$, with surfaces that were continuous and did not present visible alterations (data not shown). After 1.5 or $3 \mathrm{~h}$ of contact with the ZnO NRs in the dark, some E. coli cells displayed morphological changes that mostly appeared as flattened cells (Figure 8a,b). Meanwhile, after the photocatalytic treatment (Figure 8c,d), the majority of cells display morphological alterations with a concomitant cell size reduction that increases in a time-dependent manner. These results are in accordance with previous reports indicating the cell envelope as a primary target of the ROS generated during photocatalysis [53,54].

AFM analyses were also carried out to further support the $\mathrm{ZnO}-\mathrm{NR}$-generated morphological alteration on E. coli under light irradiation. It is noteworthy that these experiments were conducted using a cell concentration of $5 \times 10^{5} \mathrm{CFU} / \mathrm{mL}\left(10^{8} \mathrm{CFU} / \mathrm{mL}\right.$ was used in SEM experiments) and thus the damages caused to cells should be more visible than those observed by SEM analyses. Figure 9 shows AFM topography images of E. coli cells before photocatalysis (Figure 9a,d) at different magnifications, from which no surface defect could be observed (Figure 9d). The morphometric 
measurement realized on the typical bacterial cells displayed in Figure $9 \mathrm{~d}$ showed an expected size of $1 \mu \mathrm{m}$, with a ca. 400-nm width and a ca. 85-nm height. After $1.5 \mathrm{~h}$ of photocatalysis using fixed $\mathrm{ZnO}$ NRs, E. coli cells remain detectable but their rod-shape started to disappear (Figure 9b), and the size of the bacteria decreased, as shown on a randomly selected cell in Figure 9e (i.e., 800-nm length, 200-nm width, and 40-nm height). Finally, after $3 \mathrm{~h}$ of photocatalysis (Figure 9c,f), a complete lysis of the cells was observed and only thin bacterial fragments could be detected. Measurements of one of these fragments show an object with a 200-nm length, a 2-nm width, and a 2-nm thickness, which suggests an empty lysed cell.
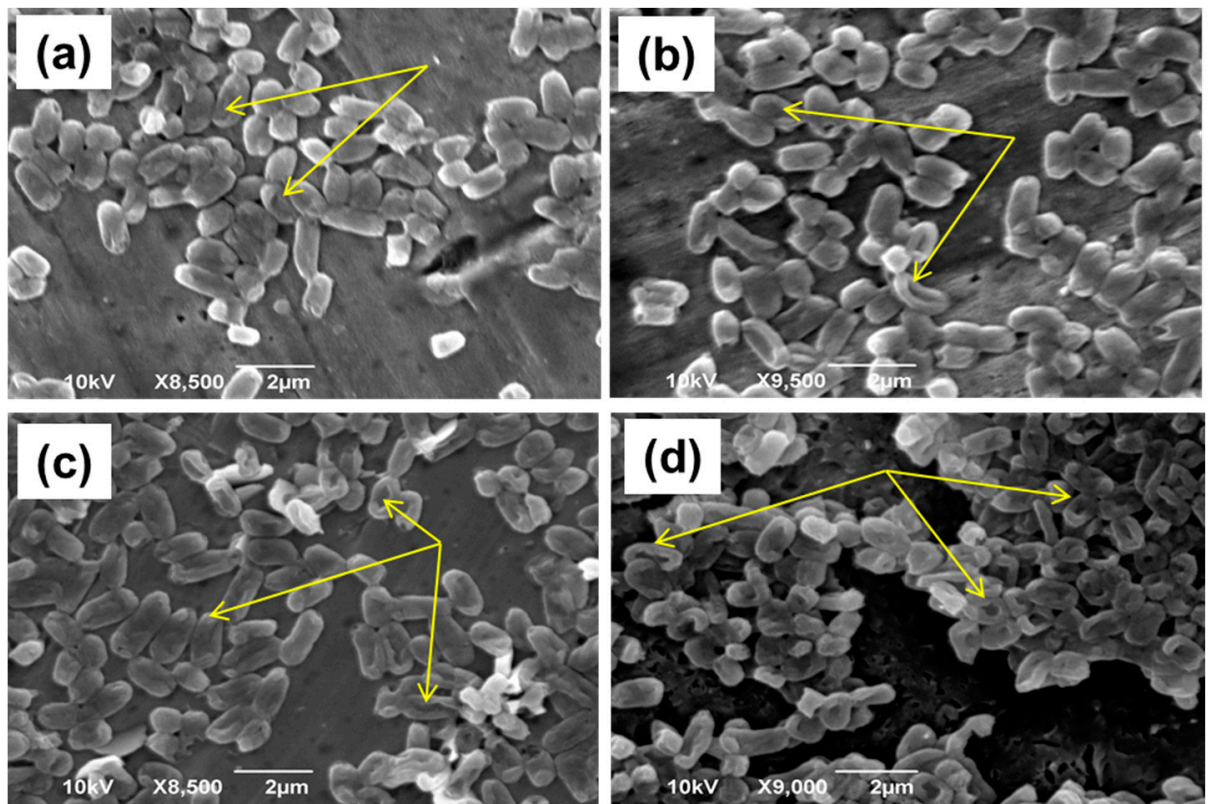

Figure 8. SEM images of E. coli MG1655 bacteria (a,b) exposed to the photocatalyst in the dark for 1.5 and $3 \mathrm{~h}$, respectively, and (c,d) exposed to the photocatalyst under light irradiation for 1.5 and $3 \mathrm{~h}$, respectively. The arrows indicate some of the most visible damaged cells.
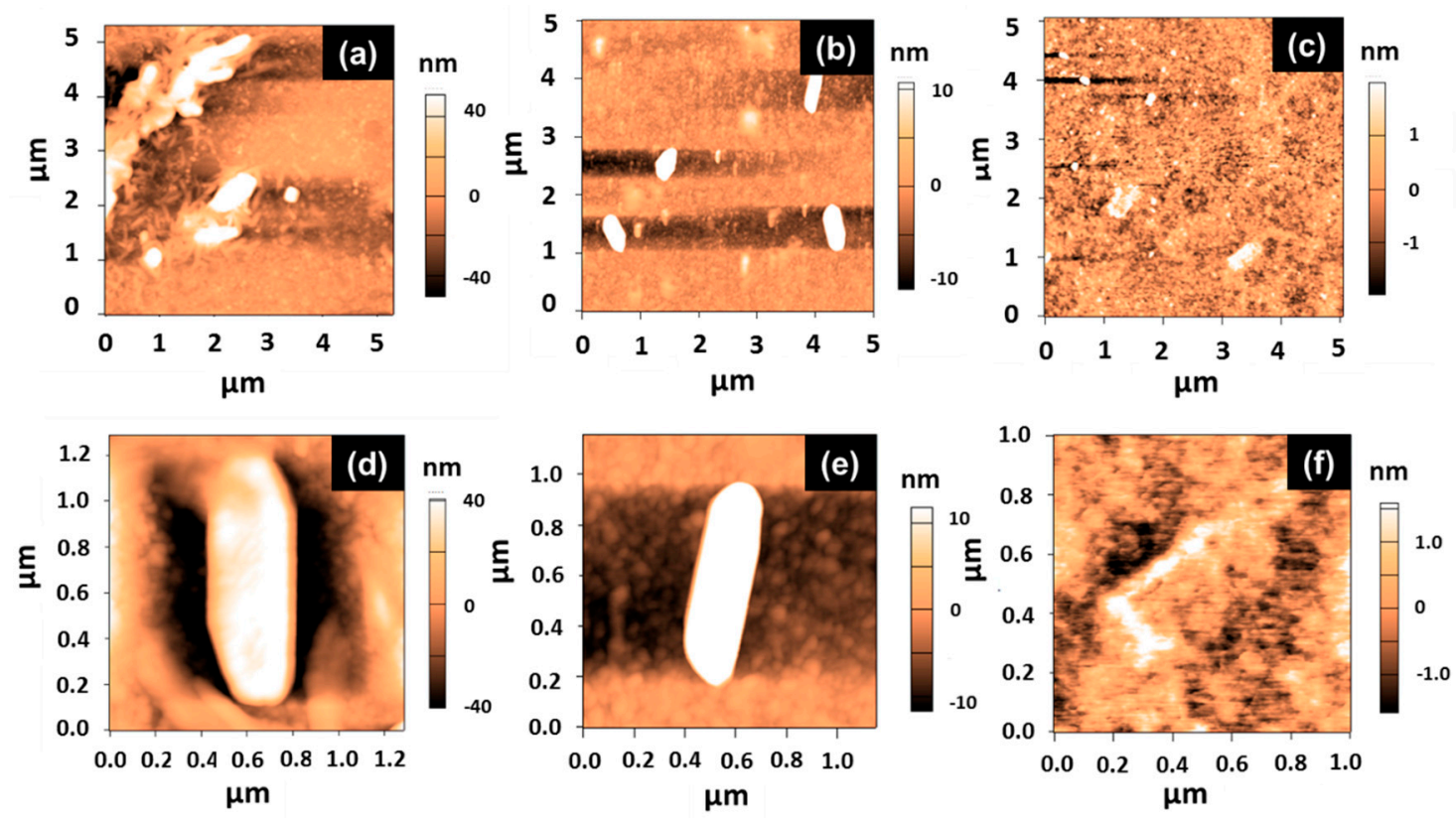

Figure 9. Atomic force microscopy (AFM) images of E. coli MG1655. (a-c) Height images at large scan and $(\mathbf{d}-\mathbf{f})$ height images at small scan $(\mathbf{a}, \mathbf{d})$ before, $(\mathbf{b}, \mathbf{e})$ after $1.5 \mathrm{~h}$, and $(\mathbf{c}, \mathbf{f})$ after $3 \mathrm{~h}$ of photocatalysis. 
Our investigations demonstrate that photocatalysis mediated by ZnO NRs mainly results in a succession of surface alterations (membrane damages, altered morphology) and that DNA is not affected. It should be noted that the alterations observed by fluorescence microscopy and FCM were not as severe as those observed by SEM and AFM. We attribute these differences to the cell sample preparation. Indeed, SEM and AFM required the samples to be dried out for observation, which is a relatively harsh condition for bacterial cells that went through a photocatalysis that damaged their surfaces. Considering that the bacterial cell envelope is responsible for its shape and it resistance to osmotic pressure, it is very likely that $\mathrm{ZnO}$-injured bacterial surfaces could not maintain the cell structure under drying conditions, which appears as cell lysis in AFM or an altered morphology of glutaraldehyde-fixed cells in SEM. Nevertheless, the most dramatic effect of photocatalysis observed by SEM and AFM results from the same surface alteration of the bacterial cells.

\section{Conclusions}

ZnO NRs with an average length and diameter of 186 and $20 \mathrm{~nm}$, respectively, were easily prepared via a low-temperature sol-gel process. These nanocrystals were found to exhibit high solar photocatalytic activity both in dispersed form or immobilized on glass for the photodegradation of the Orange II organic dye and for the E. coli bacteria decontamination. Although less photocatalytically active than the dispersed $\mathrm{ZnO}$ NRs, the immobilized rods can be easily reused at least five times for bacterial inactivation without a significant decrease in activity. Fluorescence spectroscopy, epifluorescence microscopy, SEM, and AFM provide evidence that photocatalytic treatment alters E. coli bacterial surfaces, resulting in the inactivation of the bacteria, and that inactivation occurs before intracellular damage occur, as no damage of nucleic acid could be detected. Our results demonstrate that photocatalysis using $\mathrm{ZnO}$ NRs constitutes an alternative to classical oxidation treatments such as chlorination and ozonization, especially in isolated areas, and that ZnO NRs have the potential to be used within real environmental applications.

Supplementary Materials: The following are available online at http:/ / www.mdpi.com/1996-1944/11/11/2158/ s1, Figure S1: UV-visible absorption spectrum of the light source used for photocatalytic experiments, Figure S2: (a) Room-temperature UV-visible diffuse reflectance spectra of ZnO NRs. (b) Tauc plot of ZnO NRs for the determination of the bandgap energy value, Figure S3: UV-visible spectra used to monitor the variation of the Orange II concentration as a function of irradiation time using ZnO NRs as (a) powder and (b) immobilized on glass slides, Figure S4: Plots of $\ln \left(\mathrm{C}_{0} / \mathrm{C}\right)$ vs. reaction time for the $\mathrm{ZnO}$ photocatalyst used as powder or deposited on glass slides, Figure S5: XRD patterns of the immobilized ZnO NRs (a) before and (b) after 10 successive photocatalytic cycles, Figure S6: SEM images of the immobilized ZnO NRs (a) before and (b) after 10 successive photocatalytic cycles, Figure S7: Reusability of immobilized ZnO NRs in photocatalytic bacterial inactivation, Figure S8: Influence of the amount of immobilized ZnO NRs used on the inactivation of E. coli MG1655; (a) $130 \mathrm{mg}$ and (b) $52 \mathrm{mg}$ of the photocatalyst were used, respectively, Figure S9: Time evolution of (a) Trp fluorescence emission spectra when mixing E. coli cells with ZnO NRs in the dark and (b) Trp fluorescence intensity when mixing E. coli cells with fixed ZnO NRs in the dark or under light illumination, Figure S10: Photography of the E. coli preparation under epifluorescence microscope after bacterial staining with SYBR Green II (impermeant membranes-green fluorescence) and propidium iodide (permeabilized membrane-red fluorescence). (a) Initial bacterial suspension, (b,c) control after 1 and $3 \mathrm{~h}$, respectively, (d,e) bacteria exposed to light after 1 and $3 \mathrm{~h}$, respectively, $(f, g)$ bacteria exposed to ZnO NRs in the dark after 1 and $3 \mathrm{~h}$, respectively, and (h,i) bacteria exposed to fixed ZnO NRs and to light irradiation after 1 and $3 \mathrm{~h}$, respectively, Figure S11: Representative cytograms of E. coli populations exposed or not to $\mathrm{ZnO}$ NRs before and after staining the bacterial cells with SYBR Green II fluorochromes. P1, P2, and P3 represent the gating zones illustrative of: bacterial signal before and after staining and signal parasite of control $\mathrm{NaCl}+\mathrm{ZnO}$ NRs without bacteria, respectively.

Author Contributions: F.A. prepared the photocatalytic materials and performed photodegradation experiments; C.M. and L.M. conceived and designed microbiological studies; S.C. and R.S. conceived and designed photocatalytic studies; H.A. performed AFM and SEM studies; L.B. performed TEM and SEM studies; G.M. conducted XRD experiments; M.B.S., A.G., and R.S. managed and supervised the project; all authors have read, commented on, and approved the final manuscript.

Funding: This research was partially funded by the French-Tunisian project PHC Utique CMCU 14 G0821.

Conflicts of Interest: The authors declare no conflict of interest. 


\section{References}

1. Matsunaga, T.; Tomoda, R.; Nakajima, T.; Wake, H. Photoelectrochemical sterilization of microbial cells by semiconductor powders. FEMS Microbiol. Lett. 1985, 29, 211-214. [CrossRef]

2. Karaolia, P.; Michael-Kordatou, I.; Hapeshi, E.; Drosou, C.; Bertakis, Y.; Christofilos, D.; Armatas, G.S.; Sygellou, L.; Schwartz, T.; Xekoukoulotakis, N.P.; et al. Removal of antibiotics, antibiotic-resistant bacteria and their associated genes by graphene-based $\mathrm{TiO}_{2}$ composite photocatalysts under solar radiation in urban wastewaters. Appl. Catal. B Environ. 2018, 224, 810-824. [CrossRef]

3. Regmi, C.; Joshi, B.; Ray, S.K.; Gyawali, G.; Pandey, R.P. Understanding mechanism of photocatalytic microbial decontamination of environmental wastewater. Front. Chem. 2018, 6, 33. [CrossRef] [PubMed]

4. Leyland, N.S.; Podporska-Carroll, J.P.; Browne, J.; Hinder, S.J.; Quilty, B.; Pillai, S.C. Highly efficient F, Cu doped $\mathrm{TiO}_{2}$ anti-bacterial visible light active photocatalytic coatings to combat hospital-acquired infections. Sci. Rep. 2016, 6, 24770. [CrossRef] [PubMed]

5. Helali, S.; Polo-Lopez, M.I.; Fernandez-Ibanez, P.; Ohtani, B.; Amano, F.; Malato, S.; Guillard, C. Solar photocatalysis: A green technology for E. coli contaminated water disinfection. Effect of concentration and different types of suspended catalyst. J. Photochem. Photobiol. A Chem. 2014, 276, 31-40. [CrossRef]

6. Nakano, R.; Hara, M.; Ishiguro, H.; Yao, Y.; Ochiai, T.; Nakata, K.; Murakami, T.; Kajioka, J.; Sunada, K.; Hashimoto, K.; et al. Broad spectrum microbicidal activity of photocatalysis by $\mathrm{TiO}_{2}$. Catalysts 2013, 3, 310-323. [CrossRef]

7. Wang, W.; Huang, G.; Yu, J.C.; Wong, P.K. Advances in photocatalytic disinfection of bacteria: Development of photocatalysts and mechanisms. J. Environ. Sci. 2015, 34, 232-247. [CrossRef] [PubMed]

8. Ebert, D.; Bhushan, B. Transparent, superhydrophobic, and wear-resistant coatings on glass and polymer substrates using $\mathrm{SiO}_{2}, \mathrm{ZnO}$, and ITO nanoparticles. Langmuir 2012, 28, 11391-11399. [CrossRef] [PubMed]

9. Mokari, T.; Sztrum, C.G.; Salant, A.; Rabani, E.; Banin, U. Formation of asymmetric one-sided metal-tipped semiconductor nanocrystal dots and rods. Nat. Mater. 2005, 4, 855-863. [CrossRef]

10. Phillips, J.; Bowen, W.; Cagin, E.; Wang, W. Electronic and optoelectronic devices based on semiconducting zinc oxide. Semicond. Sci. Technol. 2011, 6, 101-127. [CrossRef]

11. Wang, Z.L. ZnO nanowire and nanobelt platform for nanotechnology. Mater. Sci. Eng. R 2009, 64, 33-71. [CrossRef]

12. Xie, W.; Li, Y.; Sun, W.; Huang, J.; Xie, H.; Zhao, X. Surface modification of ZnO with Ag improves its photocatalytic efficiency and photostability. J. Photochem. Photobiol. A Chem. 2010, 216, 149-155. [CrossRef]

13. Quintana, M.; Ricra, E.; Rodriguez, J.; Estrada, W. Spray pyrolysis deposited zinc oxide films for photo-electrocatalytic degradation of methyl orange: Influence of the pH. Catal. Today 2002, 76, 141-148. [CrossRef]

14. Singh, S.; Barick, K.C.; Bahadur, D. Shape-controlled hierarchical ZnO architectures: Photocatalytic and antibacterial activities. CrystEngComm 2013, 15, 4631-4639. [CrossRef]

15. Das, J.; Khushalani, D. Nonhydrolytic route for synthesis of $\mathrm{ZnO}$ and its use as a recyclable photocatalyst. J. Phys. Chem. C 2010, 114, 2544-2550. [CrossRef]

16. Lee, K.M.; Lai, C.W.; Ngai, K.S.; Juan, J.C. Recent developments of zinc oxide based photocatalyst in water treatment technology: A review. Water Res. 2016, 88, 428-448. [CrossRef] [PubMed]

17. Girish Kumar, S.; Koteswara Rao, K.S.R. Zinc oxide based photocatalysis: Tailoring surface-bulk structure and related interfacial charge carrier dynamics for better environmental applications. RSC Adv. 2015, 5, 3306-3351. [CrossRef]

18. Sun, T.; Qiu, J.; Liang, C. Controllable fabrication and photocatalytic activity of ZnO nanobelt arrays. J. Phys. Chem. C 2008, 11, 715-721. [CrossRef]

19. Li, B.; Wang, Y.J. Facile synthesis and enhanced photocatalytic performance of flower-like ZnO hierarchical microstructures. Phys. Chem. C 2010, 114, 890-896. [CrossRef]

20. Kong, X.Y.; Wang, Z.L. Single-crystal nanorings formed by epitaxial self-coiling of polar nanobelts. Science 2004, 303, 1348-1351. [CrossRef] [PubMed]

21. Shen, J.B.; Zhuang, H.Z.; Wang, D.X.; Xue, C.S.; Liu, H. Growth and characterization of ZnO nanoporous belts. Cryst. Growth Des. 2009, 9, 2187-2190. [CrossRef] 
22. Moussa, H.; Girot, E.; Mozet, K.; Alem, H.; Medjahdi, G.; Schneider, R. ZnO rods/reduced graphene oxide composites prepared via a solvothermal reaction for efficient sunlight-driven photocatalysis. Appl. Catal. B Environ. 2016, 185, 11-21. [CrossRef]

23. Chouchene, B.; Ben Chaabane, T.; Balan, L.; Girot, E.; Mozet, K.; Medjahdi, G.; Schneider, R. High performance Ce-doped ZnO nanorods for sunlight-driven photocatalysis. Beilstein J. Nanotechnol. 2016, 7, 1338-1349. [CrossRef] [PubMed]

24. Baruah, S.; Joisai, M.; Dutta, J. Development of a visible light active photocatalytic portable water purification unit using ZnO. J. Catal. Sci. Technol. 2012, 2, 918-921. [CrossRef]

25. Zhang, X.; Qin, J.; Xue, Y.; Yu, P.; Zhang, B.; Liu, R. Effect of aspect ratio and surface defects on the photocatalytic activity of ZnO nanorods. Sci. Rep. 2014, 4, 4596. [CrossRef] [PubMed]

26. Meenakshi, G.; Sivasamy, A.; Suganya Josephine, G.A.; Kavithae, S. Preparation, characterization and enhanced photocatalytic activities of zinc oxide nano rods/silicon carbide composite under UV and visible light irradiations. J. Mol. Catal. A Chem. 2016, 411, 167-178. [CrossRef]

27. Achouri, F.; Corbel, S.; Balan, L.; Mozet, K.; Girot, E.; Medjahdi, G.; Ben Said, M.; Ghrabi, A.; Schneider, R. Porous Mn-doped $\mathrm{ZnO}$ nanoparticles for enhanced solar and visible light photocatalysis. Mater. Des. 2016, 101, 309-316. [CrossRef]

28. Rachel, A.; Subrahmanyan, M.; Boule, P. Comparison of photocatalytic efficiencies of $\mathrm{TiO}_{2}$ in suspended and immobilised form for the photocatalytic degradation of nitrobenzenesulfonic acids. Appl. Catal. B Environ. 2002, 37, 301-308. [CrossRef]

29. Arabatzis, I.M.; Antonarakis, S.; Stergiopoulos, T.; Hiskia, A.; Papaconstantinou, E.; Bernard, M.C.; Falaras, P. Preparation, characterization and photocatalytic activity of nanocrystalline thin film $\mathrm{TiO}_{2}$ catalysts towards 3,5-dichlorophenol degradation. J. Photochem. Photobiol. A 2002, 149, 237-245. [CrossRef]

30. Guo, Y.; Wang, H.; He, C.; Qiu, L.; Cao, X. Uniform carbon-coated ZnO nanorods: Microwave-assisted preparation, cytotoxicity, and photocatalytic activity. Langmuir 2009, 25, 4678-4684. [CrossRef] [PubMed]

31. Blattner, F.R.; Plunkett, G.; Bloch, C.A.; Perna, N.T.; Burland, V.; Riley, M.; Collado-Vides, J.; Glasner, J.D.; Rode, C.K.; Mayhew, G.F.; et al. The complete genome sequence of Escherichia coli K-12. Science 1997, 277, 1453-1462. [CrossRef] [PubMed]

32. Dijkstra, M.F.J.; Buwalda, H.; de Jong, A.W.F.; Michorius, A.; Winkelman, J.G.M.; Beenackers, A.A.C.M. Experimental comparison of three reactor designs for photocatalytic water purification. Chem. Eng. Sci. 2001, 56, 547-555. [CrossRef]

33. Chong, M.N.; Jin, B.; Chow, C.W.K.; Saint, C. Recent developments in photocatalytic water treatment technology: A review. Water Res. 2010, 44, 2997-3027. [CrossRef] [PubMed]

34. Daskalaki, V.M.; Frontistis, Z.; Mantzavino, D.; Katsaounis, A. Solar light-induced degradation of bisphenol-A with $\mathrm{TiO}_{2}$ immobilized on Ti. Catal. Today 2011, 161, 110-114. [CrossRef]

35. Heinlaan, M.; Ivask, A.; Blinova, I.; Dubourguier, H.C.; Kahru, A. Toxicity of nanosized and bulk ZnO, $\mathrm{CuO}$ and $\mathrm{TiO}_{2}$ to bacteria Vibrio fischeri and crustaceans Daphnia magna and Thamnocephalus platyurus. Chemosphere 2008, 71, 1308-1316. [CrossRef] [PubMed]

36. Jiang, W.; Mashayekhi, H.; Xing, B. Bacterial toxicity comparison between nano-and micro-scaled oxide particles. Environ. Pollut. 2009, 15, 1619-1625. [CrossRef] [PubMed]

37. Nair, S.; Sasidharan, A.; Divya Rani, V.V.; Menon, D.; Nair, S.; Manzoor, K.; Raina, S. Role of size scale of $\mathrm{ZnO}$ nanoparticles and microparticles on toxicity toward bacteria and osteoblast cancer cells. J. Mater. Sci. Mater. Med. 2009, 20, 235. [CrossRef] [PubMed]

38. Xie, Y.; He, Y.; Irwin, P.L.; Jin, T.; Shi, X. Antibacterial activity and mechanism of action of zinc oxide nanoparticles against Campylobacter jejuni. Appl. Environ. Microbiol. 2011, 77, 2325-2331. [CrossRef] [PubMed]

39. Premanathan, M.; Karthikeyan, K.; Jeyasubramanian, K.; Manivannan, G. Selective toxicity of ZnO nanoparticles toward Gram-positive bacteria and cancer cells by apoptosis through lipid peroxidation. Nanomed. Nanotech. Biol. Med. 2011, 7, 184-192. [CrossRef] [PubMed]

40. Li, M.; Zhu, L.; Lin, D. Toxicity of ZnO nanoparticles to Escherichia coli: Mechanism and the influence of medium components. Environ. Sci. Technol. 2011, 45, 1977-1983. [CrossRef] [PubMed]

41. Franklin, N.M.; Rogers, N.J.; Apte, S.C.; Batley, G.E.; Gadd, G.E.; Casey, P.S. Comparative toxicity of nanoparticulate $\mathrm{ZnO}$, bulk $\mathrm{ZnO}$, and $\mathrm{ZnCl}_{2}$ to a freshwater microalga (Pseudokirchneriella subcapitata): The importance of particle solubility. Environ. Sci. Technol. 2007, 41, 8484-8490. [CrossRef] [PubMed] 
42. Lele, B.S.; Russell, A.J. Rational protein modification leading to resistance of enzymes to $\mathrm{TiO}_{2}-\mathrm{UV}$ irradiation-induced inactivation. Biomacromolecules 2004, 5, 1947-1955. [CrossRef] [PubMed]

43. Akbar, S.; Sreeramulu, K.; Sharma, H.C. Tryptophan fluorescence quenching as a binding assay to monitor protein conformation changes in the membrane of intact mitochondria. J. Bioenergy Biomembr. 2016, 48, 241-247. [CrossRef] [PubMed]

44. Chatterjee, T.; Chakraborti, S.; Joshi, P.; Singh, S.P.; Gupta, V.; Chakrabarti, P. The effect of zinc oxide nanoparticles on the structure of the periplasmic domain of the Vibrio cholerae ToxR protein. FEBS J. 2010, 277, 4184-4194. [CrossRef] [PubMed]

45. Berney, M.; Weilenmann, H.U.; Egli, T. Flow-cytometric study of vital cellular functions in Escherichia coli during solar disinfection (SODIS). Microbiol. SGM 2006, 152, 1719-1729. [CrossRef] [PubMed]

46. Prütz, W.A. Hypochlorous acid interactions with thiols, nucleotides, DNA, and other biological substrates. Biochem. Biophys. 1996, 332, 110-120. [CrossRef] [PubMed]

47. Prütz, W.A. Arch. Interactions of hypochlorous acid with pyrimidine nucleotides, and secondary reactions of chlorinated pyrimidines with GSH, NADH, and other substrates. Biochem. Biophys. 1998, 349, 183-191. [CrossRef] [PubMed]

48. Phe, M.H.; Dossot, M.; Guilloteau, H.; Block, J.C. Nucleic acid fluorochromes and flow cytometry prove useful in assessing the effect of chlorination on drinking water bacteria. Water Res. 2005, 39, 3618-3628. [CrossRef] [PubMed]

49. Phe, M.H.; Dossot, M.; Block, J.C. Chlorination effect on the fluorescence of nucleic acid staining dyes. Water. Res. 2004, 38, 3729-3737. [CrossRef] [PubMed]

50. Phe, M.H.; Hajj Chehade, M.; Guilloteau, H.; Merlin, C.; Block, J.C. Assessment of damage to nucleic acids and repair machinery in Salmonella typhimurium exposed to chlorine. Int. J. Microbiol. 2009, 2009, 201868. [CrossRef] [PubMed]

51. Grégori, G.; Citterio, S.; Ghiani, A.; Labra, M.; Sgorbati, S.; Brown, S.; Denis, M. Resolution of viable and membrane-compromised bacteria in freshwater and marine waters based on analytical flow cytometry and nucleic acid double staining. Appl. Environ. Microbiol. 2001, 67, 4662-4670. [CrossRef] [PubMed]

52. Hammes, F.; Berney, M.; Wang, Y.; Vital, M.; Köster, O.; Egli, T. Flow-cytometric total bacterial counts as a descriptive microbiological parameter for drinking water treatment processes. Water Res. 2008, 42, $269-277$. [CrossRef] [PubMed]

53. Kiwi, J.; Nadtochenko, V. Evidence for the mechanism of photocatalytic degradation of the bacterial wall membrane at the $\mathrm{TiO}_{2}$ interface by ATR-FTIR and laser kinetic spectroscopy. Langmuir 2005, 21, 4631-4641. [CrossRef] [PubMed]

54. Gogniat, G.; Thyssen, M.; Denis, M.; Pulgarin, C.; Dukan, S. The bactericidal effect of $\mathrm{TiO}_{2}$ photocatalysis involves adsorption onto catalyst and the loss of membrane integrity. FEMS Microbiol. Lett. 2006, 258, $18-24$. [CrossRef] [PubMed]

(C) 2018 by the authors. Licensee MDPI, Basel, Switzerland. This article is an open access article distributed under the terms and conditions of the Creative Commons Attribution (CC BY) license (http://creativecommons.org/licenses/by/4.0/). 